\title{
PEMANFAATAN MEDIASI DALAM PERKARA PERSELISIHAN HASIL PEMILIHAN KEPALA DAERAH
}

\author{
Muchamad Arif Agung Nugroho \\ Fakultas Hukum Universitas Wahid Hasyim \\ Semarang agungnugroho@unwahas.ac.id
}

\begin{abstract}
Abstrak
Bila PMK 1/2015 dan PMK 5/2015ditafsirkan, maka perselisihan hasil pemilihan kepala daerah dipandang sebagai bagian dari ruang lingkup hukum publik sehingga perdamaian tidak diatur di dalamnya. Padahal di dalam penegakan hukum publik sangat dimungkinkan upaya damai. Akan lebih baik bila dalam perkara perselisihan hasil pemilihan kepada daerah diberi upaya hukum perdamaian melalui mediasi. Pokok masalah yang akan dibahas dalam tulisan ini adalah (1) Bagaimana prosedur mediasi dalam perkara perselisihan hasil pemilihan kepala daerah? (2) Bagaimana pengaturan prosedur mediasi dalam hukum acara perselisihan hasil pemilihan kepala daerah? Metode penelitian yang dipakai dalam tulisan ini adalah yuridis normatif, artinya penelitian ini berkutat pada pembahasan atau mengkaji peraturan-peraturan tertulis. Setelah dilakukan penelitian dan telaah ditemukan sebagai berikut: pertama, dipetakan para pihak telebih dahulu. Kedua, yang boleh menjadi mediator di dalam mediasi tersebut diutamakan mediator independen dan tersertifikasi agar posisi hakim MKRI tetap dalam keadaan objektif. Ketiga, jangka waktu proses mediasi janganlah terlalu lama. Keempat, agar mediasi efektif maka para pihak prinsipiil haruslah selalu hadir dalam proses mediasi tanpa diwakili kuasa hukumnya tetapi diperbolehkan didampingi kuasa hukumnya. Kelima, lokasi mediasi bisa dilakukan di dan difasilitasi oleh MKRI atau bisa juga di wilayah domisili hukum termohon, mengingat proses pemilihan kepala daerah berpusat di wilayah domisili hukum termohon. Keenam, mediasi yang berhasil dituangkan dalam akta perdamaian yang merupakan kesepakatan bersama antar para pihak. Ketujuh, biaya-biaya mediasi ditanggung oleh negara. Lalu, pengaturan tentang prosedur mediasi dilakukan dengan cara mengubah undang-undang tentang MKRI. Selanjutnya membuat PMK sebagai peraturan teknis prosedurnya. PMK ini ada baiknya dibuat tersendiri. Susunan atau anatomi dari PMK tentang mediasi antara lain mengatur tentang ketentuan umum, pedoman mediasi, mediator, tahapan pramediasi, tahapan proses mediasi, keterpisahan mediasi dari litigasi, perdamaian di luar pengadilan, ketentuan penutup.
\end{abstract}

Kata kunci: mediasi, perselisihan hasil pemilihan kepada daerah. 


\section{A. Pendahuluan}

Peselisihan mengandung sengketa, yang mana ada pihak yang bersengketa dengan pihak lain. Pihak-pihak yang saling berselisih sebaiknya didamaikan. Itulah jalan utama dan sudah menjadi kebiasaan berhukum di Indonesia. Jikalau perdamaian gagal dan masalah harus diselesaikan di pengadilan, maka pengadilan tetaplah harus mengupayakan perdamaian di dalam persidangan.

Secara teori, dalam penegakan hukum publik tidak dikenal perdamaian, hanya hukum privat saja yang mengenal perdamaian. Hal ini bisa dilihat pada Pasal 10 UU 48/2009 ${ }^{1}$, yang pada pokoknya, usaha penyelesaian perkara perdata secara perdamaian. Tetapi, pada kenyataannya,penyelesaian perkara secara damai bisa ditemukan diruang lingkup hukum publik walaupun dengan penggunaan istilah berbeda, seperti diversifikasi dalam sistem peradilan pidana anak. Itulah mengaparestorative justice akhir-akhir ini menjadi objek primadona dalam penelitian hukum pidana, karena memang, sepertinya, para sarjana hukum pidana sadar bahwa pemidanaan dengan cara penjara atau kurungan dirasa tidak efektif dan efisien.

Jika PMK 1/2015² dan PMK 5/2015 3 ditafsirkan, maka perselisihan hasil pemilihan kepala daerah dipandang sebagai bagian dari ruang lingkup hukum publik, itu sebabnya perdamaian tidak diatur di dalamnya. Padahal, sebagaimana saya contohkan di alinea sebelumnya, di dalam penegakan hukum publik sangat dimungkinkan upaya damai.

Perdamaian merupakan penyelesaian perkara melalui perundingan untuk memperoleh kesepakatan para pihak. Perdamaian akan lebih mudah diwujudkan jika ada penengahnya. Oleh karena itu, perdamaian dilakukan dalam proses mediasi agar ada mediator yang menengahi.

\footnotetext{
${ }^{1}$ Undang-undang Nomor 48 Tahun 2009 Tentang Kekuasaan Kehakiman

2 Peraturan Mahkamah Konstitusi Republik Indonesia Nomor 1 Tahun 2015 Tentang Pedoman Beracara dalam Perkara Perselisihan Hasil Pemilihan Gubernur, Bupati, dan Walikota

${ }^{3}$ Peraturan Mahkamah Konstitusi Republik Indonesia Nomor 5 Tahun 2015 Tentang Perubahan atas Peraturan Mahkamah Konstitusi Nomor 1 Tahun 2015 Tentang Pedoman Beracara dalam Perkara Perselisihan Hasil Pemilihan Gubernur, Bupati, dan Walikota
} 
MKRI ${ }^{4}$ pernah menyatakan bahwa pemilihan kepala daerah bukanlah rezim pemilihan umum berdasarkan UUD $1945^{5}$. Ke depannya nanti, mungkin, perkara perselisihan hasil pemilihan kepala daerah akan diselesaikan oleh badan peradilan khusus untuk menanganinya, tetapi hingga saat ini, perkara tersebut masih menjadi wewenang MKRI. Sehingga hasil pemikiran yang dituangkan dalam tulisan ini, untuk sementara ini ditujukan kepada MKRI. Kalau toh nanti wewenang tersebut dilimpahkan ke badan peradilan lain, maka pemikiran ini bisa juga diadopsi oleh badan tersebut.

Pokok masalah yang akan dibahas dalam tulisan ini adalah

1. Bagaimana prosedur mediasi dalam perkara perselisihan hasil pemilihan kepala daerah?

2. Bagaimana pengaturan prosedur mediasi dalam hukum acara perselisihan hasil pemilihan kepala daerah?

\section{B. Metode Penelitian}

Metode penelitian yang dipakai dalam tulisan ini adalah yuridis normatif, artinya penelitian ini berkutat pada pembahasan atau mengkaji peraturanperaturan tertulis. Data yang dikumpulkan adalah data primer terdiri dari peraturan perundang-undangan dan literatur-literatur hukum. Analisis data pada tulisan ini adalah deskriptif analisis dengan sifat deduktif, yaitu pembedahan permasalahan dengan penggambaran secara sistematis dan terstruktur dari menjelaskan yang umum hingga ke bagian yang teknis dan rinci.

\section{Hasil Penelitian dan Pembahasan}

\section{Prosedur Mediasi dalam Perkara Perselisihan Hasil Pemilihan Kepala Daerah}

Anatomi hukum acara perkara perselisihan hasil pemilihan kepala daerah adalah

\footnotetext{
${ }^{4}$ Mahkamah Konstitusi Republik Indonesia

${ }^{5}$ Undang-undang Dasar Negara Republik Indonesia Tahun 1945
} 
(1) Para Pihak ${ }^{6}$ :

a. Pemohon: pasangan calon kepala daerah (yang kalah);

b. Termohon: $\mathrm{KPU}^{7} / \mathrm{KIP}^{8}$ daerah;

c. Pihak Terkait: pasangan calon kepala daerah (yang menang).

(2) Objek Perkara' ${ }^{9}$ penetapan perolehan suara hasil pemilihan kepala daerah.

Adanya pihak pemohon dan termohon yang saling berhadap-hadapan mengindikasikan perkara ini mengandung sengketa dikarenakan ada dua pihak yang saling berlawanan yaitu pemohon melawan termohon. Sudah menjadi kebiasaan berhukum, bahwa suatu sengketa sebaiknya diutamakan untuk diselesaikan melalui mediasi, karena mediasi bisa menggapai keadilan subtantif melalui win win solution. Pemanfaatan mediasi dalam perkara perselisihan hasil pemilihan kepala daerah, prosedurnya bisa mengadopsi mediasi yang ada di dalam peradilan di bawah lingkungan $\mathrm{MARI}^{10}$, yaitu sebagaimana yang diatur dalam Perma $1 / 2016^{11}$.

Pertama, dipetakan para pihak telebih dahulu. Para pihak ada tiga yaitu pemohon, termohon dan pihak terkait, sehingga ketiga pihak ini haruslah dilibatkan dalam proses mediasi. Para pihak ada tiga yaitu pemohon, termohon dan pihak terkait, sehingga ketiga pihak ini haruslah dilibatkan dalam proses mediasi. Memang pihak yang berhadap-hadapan hanya ada dua, yiatu pemohon dan termohon, akan tetapi jika pihak terkait tidak dilibatkan maka akan berpotensi terrugikan bila tidak dilibatkan dalam proses mediasi. Bahkan kalau perlu, pihak terkait yang tidak memperoleh suara yang signifikan juga dilibatkan.

Kedua, yang boleh menjadi mediator di dalam mediasi tersebut diutamakan mediator independen dan tersertifikasi agar posisi hakim MKRI tetap dalam keadaan objektif. Untuk memenuhi mediator maka MKRI harus mengadakan pelatihan dan sertifikasi mediator yang khusus beracara di MKRI.

\footnotetext{
${ }^{6}$ Pasal 2 dan 3 PMK 1/2015

${ }^{7}$ Komisi Pemilihan Umum

${ }^{8}$ Komisi Independen Pemilihan

${ }^{9}$ Pasal 4 PMK 5/2015

${ }^{10}$ Mahkamah Agung Republik Indonesia

11 Peraturan Mahkamah Agung Republik Indonesia Nomor 1 Tahun 2016 Tentang Prosedur Mediasi di Pengadilan
} 
Untuk memenuhi mediator maka MKRI harus mengadakan pelatihan dan sertifikasi mediator yang khusus beracara di MKRI. Pemilihan mediator ditunjuk sendiri oleh para pihak, jika tidak maka hakim MKRI yang akan memilihkannya.

Ketiga, jangka waktu proses mediasi janganlah terlalu lama. Setidaktidaknya adalah 5 hari kerja untuk memilih mediator, 10 hari kerja untuk mediasi dan dapat diperpanjang 5 hari lagi. Jika gagal, maka mediator dalam waktu 3 hari kerja harus segera memberitahukannya kepada hakim MKRI untuk segera dilakukan proses persidangan seperti biasa. Jika gagal, maka mediator dalam waktu 3 hari kerja harus segera memberitahukannya kepada hakim MKRI untuk segera dilakukan proses persidangan seperti biasa. Jika berhasil, maka mediator memberitahukannya kepada hakim MKRI dalam jangka waktu 3 hari kerja supaya segera dikeluarkan putusan.

Keempat, agar mediasi efektif maka para pihak prinsipiil haruslah selalu hadir dalam proses mediasi tanpa diwakili kuasa hukumnya tetapi diperbolehkan didampingi kuasa hukumnya. Kehadiran prinsipiil merupakan kunci keberhasilan mediasi yang berujung pada kesepakatan damai. Kehadiran prinsipiil merupakan kunci keberhasilan mediasi yang berujung pada kesepakatan damai. Kalau prinsipiilnya selalu diwakili oleh kuasa hukumnya, maka dikhawatirkan mediasi berjalan tersendat karena komunikasi tidak berjalan langsung antar prinsipiil. Pemohon prinsipiil yang tidak hadir tanpa alasan yang sah akan berakibat hukum dikeluarkan putusan yang menyatakan permohonannya tidak dapat diterima.

Kelima, lokasi mediasi bisa dilakukan di dan difasilitasi oleh MKRI atau bisa juga di wilayah domisili hukum termohon, mengingat proses pemilihan kepala daerah berpusat di wilayah domisili hukum termohon. Mediasi bisa juga dilakukan secara telekonferensi di tempat-tempat yang ditunjuk oleh MKRI. Mediasi bisa juga dilakukan secara telekonferensi di tempat-tempat yang ditunjuk oleh MKRI.

Keenam, mediasi yang berhasil dituangkan dalam akta perdamaian yang merupakan kesepakatan bersama antar para pihak. Akta tersebut dilaporkan kepada pihak MKRI untuk dikeluarkan penetapan. Sebelum mengambil penetapan, kesembilan hakim MKRI haruslah bermusyawarah dulu dalam rapat 
permusyawaratan hakim. Dalam amar putusannya, MKRI cukup menetapkan pasangan calon kepala daerah terpilih. Akta tersebut dilaporkan kepada pihak MKRI untuk dikeluarkan penetapan. Sebelum mengambil penetapan, kesembilan hakim MKRI haruslah bermusyawarah dulu dalam rapat permusyawaratan hakim. Dalam amar putusannya, MKRI cukup menetapkan pasangan calon kepala daerah terpilih. Jadi, MKRI di sini berperan mengambil alih posisi KPU/KIP daerah sebagai pejabat tata usaha pemerintahan untuk menetapkan ulang hasil pemilihan kepala daerah. Akta perdamaian tidak diperkenankan mencantumkan kesepakatan perdata seperti kompensasi-kompensasi yang bernilai uang, karena hal itu bukan wilayah MKRI.

Ketujuh, biaya-biaya mediasi ditanggung oleh negara. Mengingat, berperkara di MKRI ditanggung oleh negara, maka sebaiknya biaya mediasi juga ditanggung oleh negara juga.

\section{Pengaturan Mediasi dalam Hukum Acara Perselisihan Hasil Pemilihan Kepala Daerah}

Pengaturan tentang prosedur mediasi, pada tahap awal dapat dilakukan dengan cara mengubah undang-undang tentang MKRI. UU 24/2003 ${ }^{12}$ yang pernah diubah dalam UU 8/2011 ${ }^{13}$ dapatdiubah kembali untuk kedua kalinya dalam rangka menampung ide tentang mediasi di dalam hukum acara Mahkamah Konstitusi.Perubahan dalam undang-undang baru bisa diletakkan pada Bab I Ketentuan Umum dan Bab V Hukum Acara

Setelah undang-undang tentang MKRI diubah, maka tahap selanjutnya membuat $\mathrm{PMK}^{14}$ sebagai peraturan teknis prosedurnya. PMK ini ada baiknya dibuat tersendiri. PMK ini ada baiknya dibuat tersendiri. Susunan atau anatomi dari PMK tentang mediasi dalam hukum acara perselisihan hasil pemilihan kepala daerah sebagai berikut:

BAB I KETENTUAN UMUM

BAB II PEDOMAN MEDIASI DI MKRI

\footnotetext{
${ }^{12}$ Undang-undang Nomor 24 Tahun 2003 Tentang Mahkamah Konstitusi

${ }^{13}$ Undang-undang Nomor 8 Tahun 2011 Tentang Perubahan Atas Undang-undang Nomor 24 Tahun 2003 Tentang Mahkamah Konstitusi

${ }^{14}$ Peraturan Mahkamah Konstitusi Republik Indonesia
} 
Bagian Kesatu: Ruang Lingkup

Bagian Kedua: Jenis Perkara Wajib Menempuh Mediasi

Bagian Ketiga: Sifat Proses Mediasi

Bagian Keempat: Kewajiban Menghadiri Mediasi

Bagian Kelima: Itikad Baik Menempuh Mediasi

Bagian Keenam: Biaya Mediasi

Bagian Ketujuh: Tempat Penyelenggaraan Mediasi

Bagian Kedelapan: Tata Kelola Mediasi di Pengadilan

\section{BAB III MEDIATOR}

Bagian Kesatu: Sertifikasi Mediator

Bagian Kedua: Tahapan Tugas Mediator

Bagian Ketiga: Pedoman Perilaku Mediator

\section{BAB IV TAHAPAN PRAMEDIASI}

Bagian Kesatu: Kewajiban Hakim Pemeriksa Perkara

Bagian Kedua: Kewajiban Kuasa Hukum

Bagian Ketiga: Hak Para Pihak Memilih Mediator

Bagian Keempat: Batas Waktu Pemilihan Mediator

Bagian Kelima: Pemanggilan Para Pihak

Bagian Keenam: Akibat Hukum Pihak Tidak Beritikad Baik

\section{BAB V TAHAPAN PROSES MEDIASI}

Bagian Kesatu: Penyerahan Resume Perkara dan Jangka Waktu Proses Mediasi

Bagian Kedua: Ruang Lingkup Materi Pertemuan Mediasi

Bagian Ketiga: Keterlibatan Ahli dan Tokoh Masyarakat

Bagian Keempat: Mediasi Mencapai Kesepakatan

Bagian Kelima: Kesepakatan Perdamaian Sebagian

Bagian Keenam: Mediasi Tidak Berhasil atau Tidak dapat Dilaksanakan

BAB VI KETERPISAHAN MEDIASI DARI LITIGASI

BAB VII PERDAMAIAN DI LUAR PENGADILAN

BAB VIII KETENTUAN PENUTUP 


\section{Penutup}

\section{Simpulan}

(1) Pertama, dipetakan para pihak telebih dahulu. Kedua, yang boleh menjadi mediator di dalam mediasi tersebut diutamakan mediator independen dan tersertifikasi agar posisi hakim MKRI tetap dalam keadaan objektif.Ketiga, jangka waktu proses mediasi janganlah terlalu lama.Keempat, agar mediasi efektif maka para pihak prinsipiil haruslah selalu hadir dalam proses mediasi tanpa diwakili kuasa hukumnya tetapi diperbolehkan didampingi kuasa hukumnya. Kelima, lokasi mediasi bisa dilakukan di dan difasilitasi oleh MKRI atau bisa juga di wilayah domisili hukum termohon, mengingat proses pemilihan kepala daerah berpusat di wilayah domisili hukum termohon. Keenam, mediasi yang berhasil dituangkan dalam akta perdamaian yang merupakan kesepakatan bersama antar para pihak. Ketujuh, biaya-biaya mediasi ditanggung oleh negara.Kelima, lokasi mediasi bisa dilakukan di dan difasilitasi oleh MKRI atau bisa juga di wilayah domisili hukum termohon, mengingat proses pemilihan kepala daerah berpusat di wilayah domisili hukum termohon. Keenam, mediasi yang berhasil dituangkan dalam akta perdamaian yang merupakan kesepakatan bersama antar para pihak. Ketujuh, biaya-biaya mediasi ditanggung oleh negara.

(2) Pengaturan tentang prosedur mediasi dilakukan dengan cara mengubah undang-undang tentang MKRI. Selanjutnya membuat PMK sebagai peraturan teknis prosedurnya. Selanjutnya membuat PMK sebagai peraturan teknis prosedurnya. PMK ini ada baiknya dibuat tersendiri. Susunan atau anatomi dari PMK tentang mediasi antara lain mengatur tentang ketentuan umum, pedoman mediasi, mediator, tahapan pramediasi, tahapan proses mediasi, keterpisahan mediasi dari litigasi, perdamaian di luar pengadilan, ketentuan penutup.Selanjutnya membuat PMK sebagai peraturan teknis prosedurnya. PMK ini ada baiknya dibuat tersendiri. Susunan atau anatomi dari PMK tentang mediasi antara lain mengatur tentang ketentuan umum, pedoman mediasi, mediator, tahapan pramediasi, tahapan proses mediasi, keterpisahan mediasi dari litigasi, perdamaian di luar pengadilan, ketentuan penutup. 


\section{Saran}

(1) MKRI harus berani melakukan terobosan hukum untuk memanfaatkan mediasi dalam menyelesaikan perkara, dengan harapan perkara bisa terselesaikan pada tahap mediasi, sehingga perkara-perkara tidak menumpuk di MKRI.

(2) Perlu dilakukan kajian mendalam tentang pemanfaatan mediasi dalam penyelesaian perkara perselisihan hasil pemilihan kepala daerah. 


\section{Daftar Pustaka}

\section{Buku}

Dwi Rezki Sri Astarini, 2013, Mediasi Pengadilan, Bandung: Alumni

Heru Widodo, 2015, Hukum Acara Perselisihan Hasil Pilkada Serentak di Mahkamah Konstitusi, Jakarta: Sinar Grafika

Jimly Asshiddiqie, 2011, Konstitusi dan Konstitusionalisme, Jakarta: Sinar Grafika

, 2015, Pengantar Ilmu Hukum Tata Negara, Jakarta:

Rajawali Pers

M. Siahaan, 2010, Hukum Acara Mahkamah Konstitusi RI, Jakarta: Bumi Aksara

Ni’matul Huda, 2012, Hukum Tata Negara Indonesia, Jakarta: Rajawali Pers

Syahrizal Abbas, 2009, Mediasi dalam Perspektif Hukum Syari'ah, Hukum Adat,

Dan Hukum Nasional, Jakarta: Prenada Media Group

Takdir Rahmadi, Mediasi: Penyelesaian Sengketa Melalui Pendekatan Mufakat, Jakarta: Rajawali Pers

\section{Peraturan Perundang-undangan}

Undang-undang Dasar Negara Republik Indonesia Tahun 1945

Undang-undang Nomor 24 Tahun 2003 Tentang Mahkamah Konstitusi

Undang-undang Nomor 8 Tahun 2011 Tentang Perubahan Atas Undang-undang

Nomor 24 Tahun 2003 Tentang Mahkamah Konstitusi

Undang-undang Nomor 48 Tahun 2009 Tentang Kekuasaan Kehakiman

Peraturan Mahkamah Agung Republik Indonesia Nomor 1 Tahun 2016 Tentang Prosedur Mediasi di Pengadilan

Peraturan Mahkamah Konstitusi Republik Indonesia Nomor 1 Tahun 2015

Tentang Pedoman Beracara dalam Perkara Perselisihan Hasil

Pemilihan Gubernur, Bupati, dan Walikota

Peraturan Mahkamah Konstitusi Republik Indonesia Nomor 5 Tahun 2015

Tentang Perubahan atas Peraturan Mahkamah Konstitusi Nomor 1

Tahun 2015 Tentang Pedoman Beracara dalam Perkara

Perselisihan Hasil Pemilihan Gubernur, Bupati, dan Walikota 